\section{Delimitation of the experience factor in the decision to select international markets by Spanish SMEs: The influence of psychic distance}

\author{
Delimitación del factor experiencia en la toma de decisión de selección \\ de mercados internacionales de las PYMEs españolas: La influencia de la \\ distancia psíquica
}

Pedro María Martínez Villar ${ }^{\mathrm{a}, *} \sim(1)$

a) Department of Management and Business Economics. University of Leon (Spain)

* Primary Contact: pedromaria05@yahoo.com (Pedro María Martínez Villar)

\begin{abstract}
The internationalization of SMEs is generally characterized by a progressive multi-stage process, in which organizations gradually acquire knowledge and skills that strengthen their commitment to the outside world. International experience - a form of autonomous accumulation of know-how that allows the understanding of potential markets - influences the decision-making process for selecting export markets. Although gradual acquisition of international experience allows an increase in export activity in more physically distant markets, this gradualist postulate does not have an indefinite validity. This paper analyzes the limits of this international experience in terms of psychic distance, examining whether those SMEs that have obtained enough international experience to develop markets of greater complexity tend to select more complex, i.e., more psychically distant, countries. The findings generally support the idea that the relationship between international experience and psychically distant markets ceases when SMEs have obtained enough international experience, after which it is the objectives of a strictly business nature which condition the decision to select potential markets. For these reasons, when the organization has obtained enough skills and international experience to develop markets of greater complexity, the managers choose to select more complex i.e., more psychically distant, countries.
\end{abstract}

Keywords: internationalization process; SMEs export; market selection; psychic distance

JEL Classification: F14; L22; M16

\begin{abstract}
Resumen
La internacionalización de la PYME se caracteriza generalmente por un proceso progresivo de varias etapas, mediante el cual las organizaciones adquieren gradualmente conocimientos y habilidades que refuerzan su compromiso con el exterior. La experiencia internacional -una forma de acumulación autónoma de know-how que permite comprender los mercados potenciales- influye en el proceso de toma de decisiones para seleccionar los mercados de exportación. Aunque la adquisición gradual de experiencia internacional permite aumentar la actividad exportadora en mercados físicamente más distantes, este postulado gradualista no tiene una validez indefinida en el tiempo. Este trabajo analiza los límites de esta experiencia internacional en términos de distancia psíquica, examinando si aquellas PYMEs que han obtenido suficiente experiencia internacional para desarrollar mercados de mayor complejidad tienden a seleccionar países más complejos, es decir, más distantes psíquicamente. Los resultados apoyan en general la idea de que, la relación entre la experiencia internacional y los mercados psíquicamente distantes cesa cuando las PYMEs han obtenido suficiente experiencia internacional, tras lo cual, son los objetivos de carácter estrictamente empresarial los que condicionan la decisión de seleccionar los mercados potenciales. Por estas razones, cuando la organización ha obtenido suficientes competencias y experiencia internacional para desarrollar mercados de mayor complejidad, los directivos optan por seleccionar países más complejos, es decir, más alejados psíquicamente.
\end{abstract}

Palabras clave: proceso de internacionalización; PYMEs exportadoras; selección de mercados; distancia psíquica Clasificación JEL: F14; L22; M16 


\section{Introduction}

The selection of an export market is a complex process, because the objective is to choose a market country in which the company must compete in a completely different environment than the domestic market in order to obtain revenues and profitability. In turn, the degree of complexity of this decision is increased because, in addition to the specific corporate strategy, it is influenced by experience, risk aversion, the ability to manage complexity and diversity, as well as various elements of motivation whose nature is psychic, and which are present in the awareness of the manager responsible for making this strategic decision.

Experience plays an essential role in the process of internationalization of the company, a role which has been dealt with extensively in the business literature. Researchers have used a wide variety of measures to assess the role of experience in the selection of potential markets. Herrmann and Datta (2006) focused on general international experience, assessing the proportion of income and assets originating from and located abroad; Drogendijk and Slangen (2006) focused their analysis on experience, more specifically, on the foreign host market; Barkema and Vermeulen (1998) focused on studying experience according to the number of countries in which the company operates; Harzing (2002) considered the years of foreign commercial activity; and Hennart and Larimo (1998) focused on the number of subsidiary foreign companies that make up the business group.

However, despite the importance given to experience, the theoretical justifications offered scarcely focus on the commercial expansion of the company through exports and, in turn, have been too complex to guarantee its synthesis (Sánchez-Marín et al., 2020). These circumstances justify this research, whose initial theoretical proposal considers experience as an intangible asset that allows the management of a firm to understand potential markets, their diversity, the needs of potential consumers, as well as competitive complexities.

The selection of export markets by similarity to the native market of the company is the motivation factor of psychic proximity which is more closely related to the concept of psychic distance. It is interesting to note that this incentive of psychic proximity exercises a moderating role on risk aversion at the beginning of the internationalization process (Monreal-Pérez \& Sánchez-Marín, 2017).

Based on the conceptualization of the gradualist theory of internationalization, proposed by the School of Uppsala (Johanson \& Wiedersheim-Paul, 1975; Johanson \& Vahlne, 1977, 1990), which associates the phenomenon of experience to psychic distance within the scope of the internationalization of the company, the same theory will be used to assess how the learning process during successive selections of export markets conditions the subsequent choices of potential markets measured in terms of complexity, diversity, and risk.

The gradualist theory and the phenomenon of psychic distance may explain and predict the influence of experience on this behavior, since the selection of potential markets favors those countries that transmit minimum uncertainty, especially during the first phases of decisions. It is a criterion of prudent non-systematic methodological choice that emphasizes that the selection of export markets is a dual decision-making process of learning and commitment.

Considering the above, the objective of this paper is twofold. Firstly, to identify the company's pattern of behavior regarding the selection of potential export markets in its first proactive exporting experiences. And secondly, to model the relationship between experience and the evolution of market-selection decisions in terms of complexity, verifying whether, as the experience factor increases, the company selects more complex potential markets, i.e., more distant in terms of psychic distance.

The analysis has focused on a sample of 377 Spanish SMEs, as they constitute the dominant business sector in Spain, and because their activity is considered to be an important source of employment and wealth creation (Merino et al., 2015). These companies have a high potential to participate in the benefits of export activity, yet there is still a long way to go compared to the most internationalized countries of the EU. In 2013, when the fieldwork for this research began, Spain had 42,469 exporters out of a total of more than three million companies, according to the Central Companies Directory.

The paper is structured as follows. First, the theory framework supporting the research hypotheses is developed. Next, the empirical methodology is described. The results obtained are then presented, followed by a discussion of the conclusions obtained.

\section{Theoretical Framework and Hypotheses}

The initial hypothesis states that the strategic export process should be deployed based on the selection of those potential markets perceived as being geographically nearby and, if possible, economically integrated and culturally similar. The acquisition of knowledge and the performance of foreign markets through experience will allow the company to select proactively in successive stages of other more complex markets. Therefore, 
experience has a gradualist influence because, in the preliminary stages of the internationalization process, the company develops successive learning phases, limiting the choice of markets to those countries more similar to the native one (Johanson \& Wiedersheim-Paul, 1975; Johanson \& Vahlne, 1977, 1990).

The presence of the experience factor in the analysis of the internationalization of the company has been extensively covered in the business literature, such that, in order to measure this factor, multiple proposals have emerged based on various factors that have been analyzed, which are difficult to quantify and whose subjective nature has not been the subject of a logical and systematic study. In this respect, authors such as Kogut and Singh (1988) and Shaver (1998) adhere to the market entry mode, arguing that an important barrier to establishing a foreign subsidiary through acquisition is the cost and complexity of integrating the two organizations. International experience works by reducing that cost and therefore implies that, as a company gains international experience, the probability that the company will access more complex and more committed countries will increase (investments and permanence). Hennart and Park (1993), and Barkema and Vermeulen (1998) argued that "the ability to deal with different competitive environments is a critical skill to develop an external market". Thus, when a company performs poorly outside of its native market, the relationship between international experience and the selection of an external market depends on the relative importance of the following two key aspects: the complexity of understanding a potential market and the ability to successfully integrate, manage and execute its activity in a new country.

A possible explanation for the ambiguity with which "experience" has been measured may be the presence of the moderating effect generated by psychic distance, a phenomenon that has not been sufficiently explored and that constitutes one of the fundamental theoretical factors of the transactionality of the company (Martínez Villar, 2016).

The phenomenon of distance is not recent, as classical economists already established the relationship between physical distance, in the strict sense of the term, and the feasibility of trading. The term "distance" has been subject to a substantial change of concept since the term was first coined and has evidently been influenced by the technological and cultural evolution of the last half-century. For these reasons, it has evolved from being a merely idiomatic-geographic vision towards a more complex construct in terms of the dimensions that constitute the nature of psychological perception. This evolution has been made possible because the linguistic and logistical aspects of exporting have taken a secondary role, due to the ease with which managers may be trained and new technologies may be adopted, factors which have made it possible to overcome the geographical obstacles of international trade.

The ability to understand a market and the difficulties of managing a business in a new competitive environment are likely to be problematic even in nearby foreign markets. However, the company, in its search for incomes and profits, must weigh up the risk-return balance (Elango \& Sethi, 2007). This principle implies that managers try to assume the lowest possible risks when designing their potential market selection strategies. Therefore, it is more likely that, in the absence of experience, the presence of psychic distance between the domestic market of the company and the potential market, limits the activity to those countries which are nearest in terms of psychic perception. Under these conditions, the gradualist theory may provide greater clarity and, as a result, the concept of psychic distance, as an explanatory variable, may be more suitable for what this theory proposes.

Experience in the field of market selection has been considered to be essentially a gradualist accumulation of knowledge, because its absence distorts information between certain competitive environments and the organization, conditioning the understanding of certain potential markets (Vahlne \& Wiedersheim-Paul, 1977; Carlson, 1974; Luostarinen, 1979). Based on this hypothesis, the first selections of potential proactive markets tend to favor those countries perceived to be closest in geographical terms and, as the learning stages overlap, export activity is deployed towards more complex markets, i.e., those which are distant in terms of psychic perception. In this way, managers reduce the level of uncertainty and risks, limiting the use of resources to face the process of internationalization of the company (Sánchez-Marín et al., 2020).

The gradualist theory proposes the concept of psychic distance as an argument that explains how companies select different available countries to develop their internationalization process. The aforementioned postulates, together with the most recent adaptations of the models by Hofstede (2001) and Elango and Sethi (2007), maintain the proposal of the Uppsala school as a common factor. The original gradualist model continues to be enriched with new contributions, such as that of this study, seeking to find a solution to the points that other researchers have made in the first publications.

Psychic distance was originally defined by Beckerman (1956) as "the set of factors that inhibit the flow of information between companies and markets". From this definition, psychic distance has attracted an increasing amount of attention in the business literature in the field of international development of firms, and the term has been linked to three fields in the internationalization of the company: the selection of international markets (Child et al., 2002; Johanson \& Wiedersheim-Paul, 1975); modes of entry used to access 
selected foreign markets (Kogut \& Singh, 1988), and analysis of the company's results in these markets under this perspective of psychic distance (Evans \& Mavondo, 2002; Stöttinger \& Schlegelmilch, 1998).

The conceptualization of psychic distance has always considered the uncertainty derived from the difficulty with which information flows from one national environment to another. The availability and adequate processing of relevant information about a market-country allow a company to gain knowledge and understanding of its unique characteristics, and therefore act in two directions: firstly, by reducing the perception of uncertainty, and, secondly, as a knowledge factor that allows an adequate measurement of the risks and benefits expected from the decisions made in this regard. Therefore, the process of selecting export markets demands "macro" information, in order to understand the competitive environment of the country, and "micro" information, in order to know the specific needs of potential consumers.

The formulation of the hypotheses that are being proposed considers psychic distance as an explanatory variable, defining it as:

The accumulation of factors of uncertainty, risk, and insecurity that foreign markets transmit as a perception to the company, in such a way that they impede or disturb the learning and understanding of an external environment. These factors constitute disturbance variables of the flow of information from another country to the company and limit the capacity of an organization to learn about these markets, the consequences of which are the circumscription of its operations to those countries closest to it in terms of psychic perception. (Martínez Villar, 2016, p.97).

Psychic distance acquires an essential role in the selection process of international markets since the decisions favor those countries that transmit minimal uncertainty. It is a subjective decision that chooses those commercial opportunities that assume the lowest possible risks, and therefore the countries selected are those which are psychically closest. The dynamic behavior of psychic distance assumes the gradualist hypothesis that, as experience and learning accumulate sequentially, companies can select increasingly complex potential markets, that is, psychically more distant in terms of language, business practices, culture, consumer behavior, etc. Therefore, the first hypothesis is as follows:

H1: As the level of experience and learning increases sequentially, the company selects more complex potential markets (more distant in psychic terms).

Langhoff (1997) and Hennart and Zeng (2002) share the premise that the company acquires knowledge to cope with new environments of greater competitive complexity based on the development of learning economies and the understanding of cultural differences in the countries where it operates. The selection of commercial opportunities in foreign markets due to psychic proximity contributes to the firm's accumulation of experience. Throughout this period of time, there has been an important development of this type of economic behavior that contributes efficiency to the internationalization of the company. For these reasons, this second hypothesis, which is the main proposed construct, describes the external development of companies as a progressive multi-stage process, in which organizations gradually acquire the knowledge and skills necessary for sequentially increasing their commitment abroad.

This gradualist phenomenon emphasizes that the selection of export markets is a dual decision-making process of commitment and learning. According to this hypothesis, the decisions for the selection of export markets are made by choosing, in the first stages, those market countries that offer a level of perception of similarity to the markets where the company already operates (Martínez Villar, 2016). During the later selection stages, once the organization has obtained the competences and the adequate international experience to develop and access more complex markets, managers choose to make selection decisions of more distant psychic markets, invalidating the gradualist postulate, with the criterion of psychic proximity being replaced by the company's own business strategy. In other words, the intention is to know if the second hypothesis, if shown to be valid, offers sequential continuity or, otherwise, to know if the main hypothesis offers limitations when the exporter has acquired significant experience in the management of foreign markets. In this respect, the second hypothesis postulates the following:

H2: From the acquisition of sufficient knowledge through experience, gradualism ceases to be an explanatory factor in the decision to select potential markets, with the company's own strategic business objectives being the main factor that influences this decision.

\section{Methodology}

\subsection{Sample}

The information with which the evidence was obtained was primary, obtained through a questionnaire survey sent to Spanish SMEs which are recurrent exporters of consumer goods. "SME" is defined in Recommendation 2003/361 / CE, which states that "The category of micro, small and medium-sized enterprises consists of 
companies that employ less than 250 people and whose annual turnover does not exceed 50 million euros, or whose annual balance sheet does not exceed 43 million euros". In the present study, recurrent exporter refers to those companies that have proactively exported during each of the last three years.

The analysis focuses on SMEs, as it is not considered desirable to combine all types of companies within the same study due to the differences between large companies and SMEs in terms of availability of resources, since it is assumed that large firms have a greater ability to overcome the limitations imposed by the construction of psychic distance when selecting international markets (Monreal-Pérez \& Sánchez-Marín, 2017). The accumulation of resources and experience, a priori, may allow larger companies to focus exclusively on specific business objectives in their export decisions without taking other considerations into account (León et al., 2018). The fact SMEs tend to lack, to differing degrees, this availability of resources means that they tend to select international markets based on different criteria. In this respect, the analysis has focused on consumer goods because the commercialization of industrial products and services offers different challenges and situations for those managers responsible for the selection and development of export markets compared to domestic ones. The marketing of services also differs from that of tangible products, since the differences of intangibility, inseparability, heterogeneity, and immediacy character are united.

Table 1 presents the technical data for obtaining primary information through the survey technique. Table 2 shows the results of the sample size calculation. The size of the population is 13,705 Spanish SMEs which are recurrent exporters of consumer goods, according to data from 2010, the year when this research began (Statistical Yearbook of Spain). The export managers of the SMEs were contacted and asked to respond to a structured questionnaire by e-mail (31.91\%), telephone (59.60\%) or face-to-face (8.49\%). We obtained a final sample of 377 firms.

Table 1. Technical file of the process of obtaining primary information through the survey technique

\begin{tabular}{|l|l|}
\hline \multicolumn{1}{|c|}{ Item } & \multicolumn{1}{c|}{$\begin{array}{c}\text { Description } \\
\text { Analysis unit }\end{array}$} \\
\hline Population & $\begin{array}{l}\text { Micro, small and medium-sized Spanish exporters of consumer goods (excluding export activities of industrial } \\
\text { goods and services). This includes individuals who carry out commercial export activities under the modality } \\
\text { of an autonomous individual. }\end{array}$ \\
\hline $\begin{array}{l}\text { Criteria for inclusion in the } \\
\text { sample }\end{array}$ & $\begin{array}{l}\text { Companies which have been exporting for at least the last three years, whose managers have been proactive } \\
\text { in their last market selection, and with a presence in at least four countries. }\end{array}$ \\
\hline Information sources & $\begin{array}{l}\text { Primary information: Self-administered personal survey. Secondary information for the establishment of } \\
\text { contacts: Free access databases of the ICEX, Chambers of Commerce and various business associations. }\end{array}$ \\
\hline Geographical scope & Spain. \\
\hline Fieldwork & From November 2012 to April 2013. \\
\hline $\begin{array}{l}\text { Effective response rate / } \\
\text { survey }\end{array}$ & $8 \%$ (after an average of 2.5 contacts per interviewee) \\
\hline $\begin{array}{l}\text { Means of obtaining the } \\
\text { questionnaires }\end{array}$ & E-mail (31.91\%), telephone surveys (59.60\%) and face-to-face (8.49\%). \\
\hline Questionnaire & Questionnaire structured in four blocks, three of which with closed questions. \\
\hline Source: Own elaboration &
\end{tabular}

Table 2. Components and results corresponding to the calculation of the sample

size

\begin{tabular}{|l|c|l|c|}
\hline \multicolumn{1}{|c|}{ Components } & \multicolumn{1}{|c|}{ Result } & Components & Result \\
\hline Sample error & $5 \%$ & Confidence level & $95 \%$ \\
\hline Heterogeneity level & $50 \%$ & Size of the statistical sample population to be surveyed & 13,705 \\
\hline $\begin{array}{l}\text { Recommended } \\
\text { sample size }\end{array}$ & 376 & Estimated responses to questionnaires issued & $66 \%$ \\
\hline
\end{tabular}

Source: Own elaboration

\subsection{Measures}

Table 3 shows the measurement of variables for the seven-dimensional components of the psychic distance of our model: language, economic system, religion, culture, legal system, public freedoms, and political risk. The score of the components is taken from UN publications, specifically "Social Indicators", "The World Statistics Pocketbook, 2011" and "Statistical Yearbook", corresponding to issue no. 54. The existing differences for each criterion have been scored according to the native country of the respondents. The level of differences is an indicator of the degree of psychic distance, such that each component is given a value of zero, one or two based on the criteria of near (0), distant (1) and very distant (2). The total psychic distance is the result of the sum of the scores of the factors that make up the proposed construct, such that the values range from 0 to 12 , where 0 is a country without any differences for the six factors scored, and 12, which corresponds to those countries for which all the factors were rated as "very distant". 
Table 3. Dimensional components of the construct and their weighting

\begin{tabular}{|c|c|c|}
\hline Component & Criterion & Assignment of values \\
\hline Language (C1) & Dominant language & $\begin{array}{l}\text { (0) Spanish is the official language. (1) English-speaking countries and those } \\
\text { whose language is Latin-based. (2) Countries that do not meet either requirement. }\end{array}$ \\
\hline $\begin{array}{l}\text { Economic system } \\
(\mathrm{C} 2)\end{array}$ & $\begin{array}{l}\text { Degree of freedom for the } \\
\text { performance of commercial } \\
\text { activity }\end{array}$ & $\begin{array}{l}\text { (0) countries with a free-market economy (public sector weight less than } 50 \% \text { of } \\
\text { GDP). ( } 1 \text { ) free-market countries that exceed this parameter. (2) countries with a } \\
\text { planned economy. }\end{array}$ \\
\hline Religion (C3) & Predominant religion & $\begin{array}{l}\text { (0) countries where the Catholic religion is the majority (more than } 75 \% \text { of the } \\
\text { population). (1) countries of non-Catholic Christian preponderance. (2) countries } \\
\text { whose majority religion is non-Christian. }\end{array}$ \\
\hline Culture (C4) & $\begin{array}{l}\text { Development and urban } \\
\text { concentration }\end{array}$ & $\begin{array}{l}\text { (0) countries where the concentration of the population in cities is greater than } \\
70 \% \text {. (1) countries where this parameter is between } 50-70 \% \text {. (2) countries where } \\
\text { most of the population resides in rural areas. }\end{array}$ \\
\hline Legal system (C5) & Predominant system & $\begin{array}{l}\text { (0) countries where the legal system is continental or civil code. (1) countries with } \\
\text { a common law legal system. (2) countries whose legal system is different from (0) } \\
\text { and (1). }\end{array}$ \\
\hline $\begin{array}{l}\text { Public freedoms } \\
\text { (C6) }\end{array}$ & $\begin{array}{l}\text { Existence of a parliamentary } \\
\text { system of direct election and } \\
\text { independence of legislative- } \\
\text { executive- judicial powers }\end{array}$ & $\begin{array}{l}\text { (0) countries where these requirements are met. (1) countries where democratic } \\
\text { processes occur but there is no independence of public powers. (2) non- } \\
\text { democratic countries. }\end{array}$ \\
\hline Political risk (C7) & $\begin{array}{l}\text { Combination of two parameters: } \\
\text { country risk premium and } \\
\text { institutional stability. }\end{array}$ & $\begin{array}{l}\text { (0) countries whose risk premium, as of December } 31,2011 \text {, was with spreads } \\
\text { below interest rate differentials of }+100 \% \text { p.b. without changes in their political- } \\
\text { institutional systems in the last } 20 \text { years. (1) countries that meet one of the two } \\
\text { related parameters, }(2) \text { countries that do not meet either of these requirements. }\end{array}$ \\
\hline
\end{tabular}

Source: Own elaboration

Note: The score (0) is associated with "neighboring countries" concerning the valued component, (1) corresponds to "distant" countries; and (2) to "very distant" countries)

\subsection{Analysis}

The hypotheses testing is based on the cascade of proactive sequences of the selection of countries carried out by each firm surveyed, associating the corresponding score of psychic distance of each country with each sequence of market selection. To this end, we were required to design an experiment that allows us to measure the psychic distance of countries with respect to Spain. The model was created to assess, as an experience factor, the psychic distance associated with the successive proactive sequences of internationalization. The analysis techniques to be used to verify the hypotheses are based on descriptive statistics, as well as the use of regression techniques, specifically to test the first and second hypotheses.

\section{Results}

Table 4 shows the values obtained for psychic distance (dependent variable) for each export sequence (independent variable), which is the experience factor that will be used to verify the hypotheses proposed. Specifically, up to 11 selections of export markets are analyzed for the set of exporters surveyed. Figure 1 graphically presents the behavior of the psychic distance associated with each export sequence (experience).

Table 4. Main results of psychic distance associated with the N-sequence

\begin{tabular}{|c|c|c|c|c|c|c|c|c|c|c|c|}
\hline Sequence & 1 & 2 & 3 & 4 & 5 & 6 & 7 & 8 & 9 & 10 & $>=11$ \\
\hline $\begin{array}{l}\text { Psychic distance } \\
\text { (mean) }\end{array}$ & 2.00 & 2.73 & 3.99 & 5.76 & 5.69 & 6.03 & 5.87 & 5.69 & 5.78 & 6.13 & 5.94 \\
\hline Typical deviation & 1.62 & 2.59 & 3.86 & 3.10 & 4.01 & 3.72 & 4.47 & 2.46 & 3.51 & 3.58 & 3.54 \\
\hline $\begin{array}{l}\text { Country } \\
\text { concentration } \\
(75 \%)\end{array}$ & 5 & 10 & 19 & 22 & 24 & 30 & 28 & 24 & 26 & 29 & 30 \\
\hline $\begin{array}{l}\text { Number of } \\
\text { exporters }\end{array}$ & 377 & 377 & 377 & 345 & 295 & 250 & 212 & 174 & 132 & 82 & 34 \\
\hline
\end{tabular}

Source: Own elaboration

The results show that there is a high concentration of export market selection decisions during the first phases of the commercial internationalization process, with these decisions corresponding to those countries that are close or similar to the home country of the company. The descriptive statistics detect that, up to the fifth export sequence, a gradualist relationship occurs along the previous export sequences, while observing an ascending relationship between the experience factor and the psychic distance associated with the sequence, a phenomenon that is more intense in the first phases of the export process. As the experience factor increases, there is a dispersion of the decision as the order of sequences progresses, since there is a significant increase in the number of countries that make up the range of markets, increasing the associated psychic distance when compared to the first sequences. 
Figure 1. Behavior of psychic distance associated with its factors of experience and concentration of SME decisions

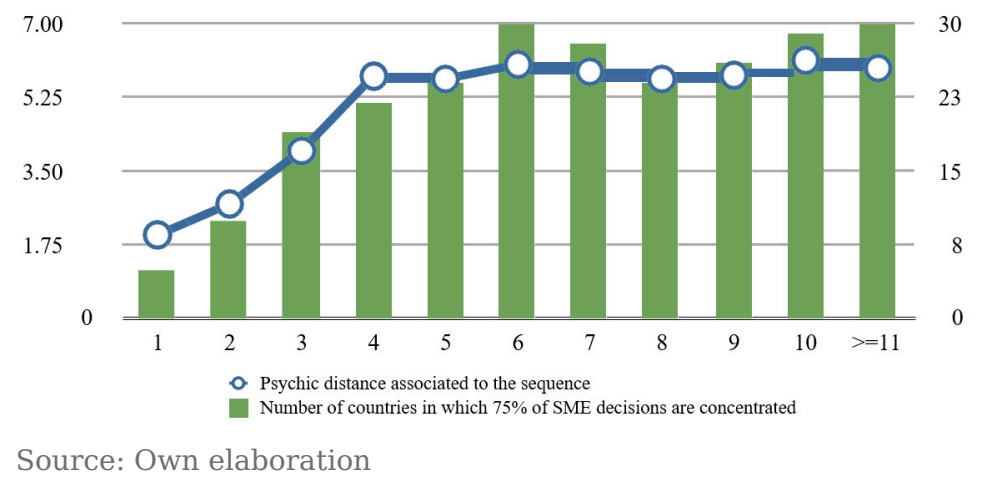

From these descriptive statistics, we can observe that, in the absence of experience, the company tends to choose those commercial opportunities that assume the lowest possible risks, since it is observed that the market selections are assigned to neighboring countries in terms of psychic distance, concentrating their selection decisions on those countries with a similar culture, with minimal politico-legal risk, which are economically integrated, and whose commercial practices are predictable.

To test the first hypothesis, the different sequences made up of the number of export destination countries will be modelled, describing the relationships between the different sequences and the values associated with psychic distance, thus verifying whether, as experience increases, the company consistently selects more complex markets i.e., more distant in psychic terms.

The regression statistical technique will be used to verify or reject this hypothesis because it will allow us to identify whether the gradualness of the selection decisions is really related to the assessment of the psychic distance associated with the decision, or whether, on the contrary, the observation carried out from the descriptive statistics is rejected. From the results of Table 5, the reliability of the different regressions obtained is analyzed. The first part of the analysis is centered on the "corrected R squared" coefficients and the errors of the regression, while considering the graphical analysis of the generated curve and putting it in context with the descriptive results analyzed previously.

Table 5. Results obtained for each regression model with the goodness of fit measurement coefficients

\begin{tabular}{|l|l|l|l|l|l|}
\hline \multicolumn{1}{|c|}{ Modeling } & R & R square & $\begin{array}{c}\text { R } \\
\text { squared } \\
\text { corrected }\end{array}$ & $\begin{array}{c}\text { Typical } \\
\text { error }\end{array}$ & \multicolumn{1}{|c|}{$\begin{array}{c}\text { Form of the graph adapted to the } \\
\text { descriptive }\end{array}$} \\
\hline Compound & 0.788 & 0.621 & 0.579 & 0.235 & Valid only in part of the interval \\
\hline Increase & 0.778 & 0.605 & 0.561 & 0.252 & Valid only in part of the interval \\
\hline Quadratic & 0.949 & 0.900 & 0.875 & 0.499 & Partially explains the behavior \\
\hline Cubic & 0.977 & 0.955 & 0.936 & 0.357 & Partially explains the behavior \\
\hline Exponential & 0.788 & 0.621 & 0.579 & 0.235 & Partially explains the behavior \\
\hline Reverse & 0.938 & 0.880 & 0.867 & 0.515 & Partially explains the behavior \\
\hline Linear & 0.827 & 0.685 & 0.650 & 0.835 & Partially explains the behavior \\
\hline Logarithmic & 0.925 & 0.856 & 0.841 & 0.582 & Valid in part of the interval \\
\hline Logistics & 0.788 & 0.621 & 0.579 & 0.235 & Adapted to the behavior \\
\hline Power & 0.929 & 0.863 & 0.848 & 0.141 & Valid in part of the interval \\
\hline S Curve & 0.960 & 0.922 & 0.913 & 0.107 & Adapted to the behavior \\
\hline
\end{tabular}

Source: Own elaboration

Note: The independent variable is SEQUENCE

The two regression models that, based on the value of the corrected $\mathrm{R}^{2}$, acquire better reliability are the cubic and the S-curve models, since they offer explanatory percentages of the total variation above $90 \%$. The adjustment of the regression curves offers a high level of quality, acquiring the capacity to replicate the results to a high percentage. In the case of cubic regression, this value is 0.936 and for the S-Curve, 0.913; therefore, it is considered that, based on these values, both regressions constitute the most adequate estimates of the goodness of population fit. From here, it can be considered that the construction of the most adapted and reliable regression function can be made with the S-Curve, since, a priori, this curve is the most appropriate because it offers a higher level of quality regarding goodness of fit. With S-curve modelling, Table 6 shows the capacity to explain the relationship between the value acquired by the psychic distance and the associated export sequence. 
Table 6. Analysis of the variance of the S-Curve regression

\begin{tabular}{|l|c|c|c|c|c|}
\hline & Sum of square & $\begin{array}{c}\text { degrees of } \\
\text { freedom }\end{array}$ & $\begin{array}{c}\text { Mean } \\
\text { quadratic }\end{array}$ & \multicolumn{2}{|c|}{ F } \\
\hline $\begin{array}{l}\text { Regres } \\
\text { sion }\end{array}$ & 1.207 & 1 & 1.207 & 105.923 & 0.000 \\
\hline $\begin{array}{l}\text { Residu } \\
\text { al }\end{array}$ & 0.103 & 9 & 0.011 & & \\
\hline Total & 1.309 & 10 & & & \\
\hline
\end{tabular}

Based on the data and interpretation obtained from the regression analysis, statistical evidence is obtained which confirms the existence of a gradualist relationship, and which therefore confirms the hypothesis that, as the level of experience and learning increases sequentially, the company selects more complex potential markets i.e., more distant in terms of psychic distance. It is necessary to clarify that the observed behavior of this relationship is not linear since the coefficient of determination indicates that the linear regression only represents $65 \%$ of the total variance explained by this function.

Finally, Figure 2 graphically represents the point cloud (observations) against the S function obtained in the regression analysis according to the following modelling of the S-curve: $D P S=e^{(1,938+(-1,287 / \text { Sequence }))}$.

The behavior of the S-curve approaches that observed in Figure 2, assuming that more intense gradualism occurs in the first selection sequences of markets, reaches a point where the psychic distance relationship is stabilized with respect to the experience of the exporter.

Figure 2. Graphical representation of the observations and the S function obtained in the regression analysis

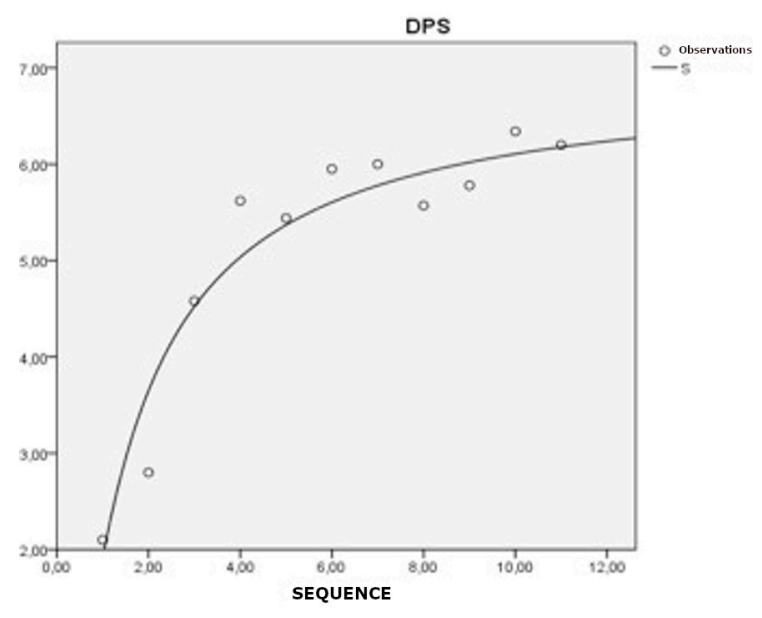

Source: Own elaboration

From here, the next objective of the research aims to verify the second proposed hypothesis, which aims to question the validity of the model, thus allowing us to delimit the validity of the first hypothesis in the field of experience. Again, regression is used to find out whether the deduction made from the observation of descriptive statistics is reasonable. Specifically, we test whether there is a consistent relationship between psychic distance and the experience factor from the fifth selection of markets, a circumstance in which the company assumes that it has enough experience to export successfully to more complex markets than those initially selected, for the acquired value of psychic distance (value> 5.69).

Table 7 shows the results obtained for each regression model corresponding to the association of psychic distance with the sequences comprised of numbers 5 to N. From the results of the goodness of fit measurement coefficients, we concluded that the regressions are not influential, and therefore it cannot be determined that there is an association between both variables. Therefore, the second hypothesis is confirmed, which postulates that, when there is a high level of experience on the part of the exporter, there is no dependence between the psychic distance associated and the experience factor. 
Table 7. Results obtained for each regression model with the goodness of fit measurement coefficients corresponding to sequences N 5-21

\begin{tabular}{|l|c|c|c|c|}
\hline \multicolumn{1}{|c|}{ Modeling } & R & R square & $\begin{array}{c}\text { R squared } \\
\text { corrected }\end{array}$ & Typical error \\
\hline Compound & 0.524 & 0.274 & 0.183 & 0.355 \\
\hline Increase & 0.524 & 0.274 & 0.183 & 0.355 \\
\hline Quadratic & 0.563 & 0.317 & 0.122 & 3.064 \\
\hline Cubic & 0.566 & 0.321 & -0.019 & 3.301 \\
\hline Exponential & 0.524 & 0.274 & 0.183 & 0.355 \\
\hline Reverse & 0.536 & 0.288 & 0.199 & 2.927 \\
\hline Linear & 0.562 & 0.316 & 0.231 & 2.868 \\
\hline Logarithmic & 0.559 & 0.312 & 0.226 & 2.876 \\
\hline Power & 0.515 & 0.265 & 0.174 & 0.357 \\
\hline S & 0.491 & 0.241 & 0.146 & 0.363 \\
\hline
\end{tabular}

Source: Own elaboration

Note: The independent variable is SEQUENCE

We carried out a complementary regression analysis to test more deeply the relationship between psychic distance and the experience of the company. The dependent variable is the value of the associated psychic distance, and the independent variable measures the years of export activity of the company, from a transformed variable that grouped years into a series of intervals. Table 8 shows the values that are subjected to regression analysis, and whose results are presented in Table 9. The measurement coefficients of the goodness of fit corresponding to the psychic distance and export experience relationship are analyzed, and all the presented values are close to zero, a circumstance that shows that the measurement of the degree of adjustment of the line or regression curve is practically nil.

Table 8. Transformed values and results of the psychic distance association and experience in years exporting in the $\mathrm{N}$-sequence

\begin{tabular}{|c|c|c|c|c|c|}
\hline $\begin{array}{c}\text { Company export } \\
\text { experience interval }\end{array}$ & $\begin{array}{l}\text { Transforme } \\
\text { d value }\end{array}$ & $\begin{array}{c}\text { Psychic distance } \\
\text { associated with the } \\
\text { interval }\end{array}$ & $\begin{array}{c}\text { Company export } \\
\text { experience interval }\end{array}$ & $\begin{array}{l}\text { Transforme } \\
\text { d value }\end{array}$ & $\begin{array}{l}\text { Psychic distance } \\
\text { associated with the } \\
\text { interval }\end{array}$ \\
\hline Up to 5 years & 1 & 5.33 & From 18 to 22 years old & 6 & 5.86 \\
\hline From 7 to 10 years & 3 & 6.69 & From 25 to 30 years & 8 & 5.01 \\
\hline From 10 to 14 years old & 4 & 6.11 & From 30 to 40 years & 9 & 6.08 \\
\hline From 14 to 18 years old & 5 & 5.82 & More than 40 years & 10 & 5.94 \\
\hline
\end{tabular}

Source: Own elaboration

Table 9. Results of the goodness of fit corresponding to the relationship between psychic distance and experience

\begin{tabular}{|c|c|c|c|c|}
\hline Modeling & $\mathbf{R}$ & R squared & $\begin{array}{l}\text { R squared } \\
\text { corrected }\end{array}$ & Typical error \\
\hline Linear & 0.082 & 0.007 & -0.117 & 0.648 \\
\hline Exponential & 0.083 & 0.007 & -0.117 & 0.108 \\
\hline Logistics & 0.077 & 0.006 & -0.118 & 0.336 \\
\hline
\end{tabular}

Source: Own elaboration

Years exporting in N-sequence

These results confirm hypothesis 2 , since there is no evidence to justify the presence of a relationship between the psychic distance corresponding to the last decision to select export markets and years of experience of the Spanish SME in exporting consumer goods. Therefore, the degree of proximity or psychological distance corresponding to the market country selection analyzed is independent of the degree of experience of the company measured in time.

\section{Conclusions and Discussion}

During the early stages of the internationalization process, SMEs generally tend to choose to internationalize in geographically nearby market countries, with a subsequent dispersion of decisions as the sequence order progresses. In particular, there is an increase in the number of potential market countries after the second selection of export markets (Monreal-Pérez \& Sánchez-Marín, 2017). In the absence of experience, SMEs tend to choose to export to those potential export markets that involve assuming the lowest possible risks, since the selection decisions of potential markets are concentrated in those countries that are more similar to the native country. 
The experience factor allows SMEs to face the phenomenon of psychic distance, which is more intensely present in the early stages of commercial internationalization of the company. Experience acquires value as an intangible asset that allows the development of complex potential markets when measured as the number of proactive decisions to enter a market country, and there is no evidence to justify this association when experience is measured simply in terms of time spent exporting to the same range of stable markets.

Regarding the psychological distance associated with the sequences, an upward trend in the level of psychic distance is detected as new export decisions are made by the managers of SMEs. In this sense, the range of countries included in the selection decisions in the early stages is characterized by a predominance of nearby countries in terms of psychic distance. However, in successive phases, the range of countries grows by incorporating new markets which are more distant in terms of psychic distance, thus expanding the range of potential decisions.

The phenomenon of psychic distance (Beckerman, 1956; Child et al., 2002), whose intensity is attributed to cultural differences, consumption habits, socioeconomic differences, political risk, as well as other difficulties in understanding the way of doing business in a foreign country, creates obstacles and barriers to learning that impede the development of commercial export operations. Based on this premise, the experience gained from the previous selections helps the managers of SMEs to make subsequent decisions to select export markets that evolve progressively towards more psychically distant countries.

This gradualist behavior limits the scope of external development of the SMEs to those countries which are geographically nearby in the first selections of export markets (Vahlne \& Johanson, 2002). In this way, the decisions to select export markets are limited to certain countries perceived as being nearby in terms of psychic perception. In this way, the managers of SMEs tend to reduce the level of uncertainty and risks of the selection process and limit the use of resources necessary to face the process of commercial internationalization (Sánchez-Marín et al., 2020). Subsequently, the company assumes, in successive phases, new more psychically distant markets, such that the accumulated experience allows them to undertake more complex selections.

The identified gradualist behavior does not occur indefinitely (Barkema \& Vermeulen, 1998). It has been shown that there is a weakening of the relationship between the value of the psychic distance associated with the experience factor from the fourth proactive decision to enter a country. The strong dependence observed in the first phases of the search for potential markets between the value of psychic distance and the associated export sequence is not explained so intensely when the company feels capable of dealing with more complex markets, and other criteria which are merely of business strategy are those that subordinate the decisions of commercial internationalization.

However, the increase in dispersions that occurs in the successive sequences should be assessed while considering that each SME selects export markets based on their particular interests, experiences, capabilities and resources. The generalization of conclusions should always be made with caution, especially when, with each new sequence, the statistically representative sample increases the level of diversity of decisions. In other words, the progress of the exporters describes an evolution from the subjectivity of the component of psychic distance in the initial stages towards greater objectivity centered on the material aspects of the business once the necessary experience has been acquired.

Finally, experience, measured by the number of market selections carried out, is the main resource that allows managers to expand the capacity to choose potentially more complex countries. However, the accumulation of experience stabilizes, to a certain degree, the value of psychical distance, such that this relationship no longer presents a multistage gradualist behavior. No evidence was found to justify the presence of a relationship between the psychical distance corresponding to the SMEs' last export market selection decision and their experience in exporting measured in time, specifically in years. Therefore, the degree of proximity or psychological distance corresponding to the market country selection analyzed is independent of the degree of experience measured in time. 


\section{References}

Barkema, H. G., \& Vermeulen, F. (1998). International expansion through start-up or acquisition: A learning perspective. Academy of Management Journal, 41(1), 7-26. https://doi.org/10.2307/256894

Beckerman, W. (1956). Distance and the Pattern of Intra-European Trade. The Review of Economics and Statistics, 38(1), 31. https://doi.org/10.2307/1925556

Carlson, S. (1974). International Transmission of Information and the Business Firm. The ANNALS of the American Academy of Political and Social Science, 412(1), 55-63. https://doi.org/10.1177/000271627441200107

Child, J., Hong Ng, S., \& Wong, C. (2002). Psychic Distance and Internationalization: Evidence from Hong Kong Firms. International Studies of Management \& Organization, 32(1), 36-56. https://doi.org/10.1080/00208825.2002.11043656

Drogendijk, R., \& Slangen, A. (2006). Hofstede, Schwartz, or managerial perceptions? The effects of different cultural distance measures on establishment mode choices by multinational enterprises. International Business Review, 15(4), 361-380. https://doi.org/10.1016/j.ibusrev.2006.05.003

Elango, B., \& Sethi, S. P. (2007). An exploration of the relationship between country of origin (COE) and the internationalization-performance paradigm. Management International Review, 47(3), 369-392. https://doi.org/10.1007/s11575-007-0021-5

Evans, J., \& Mavondo, F. T. (2002). Psychic Distance and Organizational Performance: An Empirical Examination of International Retailing Operations. Journal of International Business Studies, 33(3), 515-532. https://doi.org/10.1057/palgrave.jibs.8491029

Harzing, A. W. (2002). Acquisitions versus greenfield investments: international strategy and management of entry modes. Strategic Management Journal, 23(3), 211-227. https://doi.org/10.1002/smj.218

Hennart, J., \& Larimo, J. (1998). The Impact of Culture on the Strategy of Multinational Enterprises: Does National Origin Affect Ownership Decisions? Journal of International Business Studies, 29(3), 515-538. https://doi.org/10.1057/palgrave.jibs.8490005

Hennart, J., \& Park, Y. (1993). Greenfield vs. Acquisition: The Strategy of Japanese Investors in the United States. Management Science, 39(9), 1054-1070. https://doi.org/10.1287/mnsc.39.9.1054

Hennart, J. F., \& Zeng, M. (2002). Cross-Cultural Differences and Joint Venture Longevity. Journal of International Business Studies, 33(4), 699-716. https://doi.org/10.1057/palgrave.jibs.8491040

Herrmann, P., \& Datta, D. K. (2006). CEO Experiences: Effects on the Choice of FDI Entry Mode. Journal of Management Studies, 43(4), 755-778. https://doi.org/10.1111/j.1467-6486.2006.00610.x

Hofstede, G. (2001). Cultures consequences. Comparing values, behaviours, institutions, and organizations across nations. Sage Publications

Johanson, J., \& Vahlne, J. (1977). The Internationalization Process of the Firm-A Model of Knowledge Development and Increasing Foreign Market Commitments. Journal of International Business Studies, 8(1), 23-32. https://doi.org/10.1057/palgrave.jibs.8490676

Johanson, J., \& Vahlne, J. (1990). The Mechanism of Internationalisation. International Marketing Review, 7(4), 02651339010137414. https://doi.org/10.1108/02651339010137414

Johanson, J., \& Wiedersheim-Paul, F. (1975). The internationalisation process of the firm. Four Swedish Case Studies. Journal of Management Studies, 12(3), 305-323. https://doi.org/10.1111/j.1467-6486.1975.tb00514.x

Kogut, B., \& Singh, H. (1988). The Effect of National Culture on the Choice of Entry Mode. Journal of International Business Studies, 19(3), 411-432. https://doi.org/10.1057/palgrave.jibs.8490394

Langhoff, T. (1997). The influence of cultural differences on internationalisation processes of firms: an introduction to a semiotic and intercultural perspective. In I. Björkman, \& M. Forsgren (Eds.), The nature of the international firm. Handelshøjskolens Forlag

León, O., Igartua, J. I., \& Ganzarain, J. (2018). Performance and internationalization effects of the use of ICT in diversified companies. Small Business International Review, 2(1), 16-28. https://doi.org/10.26784/sbir.v2i1.22

Luostarinen, R. (1979). Internationalization of the firm. Acta Academiae Oeconomicae Helsingiensis. A Fennica

Martínez Villar, P. M. (2016). La distancia psíquica en el ámbito de la selección de mercados internacionales: propuesta de definición y presencia en las PYMEs españolas exportadoras de bienes de consumo. Pecvnia : Revista de la Facultad de Ciencias Económicas y Empresariales, Universidad de León, 23, 89. https://doi.org/10.18002/pec.v0i23.5136

Merino, F., Monreal-Pérez, J., \& Sánchez-Marín, G. (2015). Family SMEs' Internationalization: Disentangling the Influence of Familiness on Spanish Firms' Export Activity. Journal of Small Business Management, 53(4), 1164-1184. https://doi.org/10.1111/jsbm.12111 
Monreal-Pérez, J., \& Sánchez-Marín, G. (2017). Does transitioning from family to non-family controlled firm influence internationalization? Journal of Small Business and Enterprise Development, 24(4), 775-792. https://doi.org/10.1108/JSBED-02-2017-0029

Shaver, J. M. (1998). Accounting for Endogeneity When Assessing Strategy Performance: Does Entry Mode Choice Affect FDI Survival? Management Science, 44(4), 571-585. https://doi.org/10.1287/mnsc.44.4.571

Stöttinger, B., \& Schlegelmilch, B. B. (1998). Explaining export development through psychic distance: enlightening or elusive? International Marketing Review, 15(5), 357-372. https://doi.org/10.1108/02651339810236353

Sánchez-Marín, G., Pemartín, M., \& Monreal-Pérez, J. (2020). The influence of family involvement and generational stage on learning-by-exporting among family firms. Review of Managerial Science, 14(1), 311-334. https://doi.org/10.1007/s11846-019-00350-7

Vahlne, J., \& Johanson, J. (2002). New technology, new companies, new business environment and new internationalisation processes. In M. Forsgren, V. Havila, \& H. H\aakansson (Eds.), Critical Perspectives on Internationalization. Pergamon

Vahlne, J., \& Wiedersheim-Paul, F. (1977). Psychic distance. An inhibiting factor in international trade. University of Uppsala 